\title{
Eco-environmental impact of inter-basin water transfer projects: a review
}

\author{
Wen Zhuang ${ }^{1,2}$
}

Received: 8 December 2015 / Accepted: 9 May 2016/Published online: 14 May 2016

(C) Springer-Verlag Berlin Heidelberg 2016

\begin{abstract}
The objective reality of uneven water resource distribution and imbalanced water demand of the human society makes it inevitable to transfer water. It has been an age-old method to adopt the inter-basin water transfers (IBTs) for alleviating and even resolving the urgent demand of the waterdeficient areas. A number of countries have made attempts and have achieved enormous benefits. However, IBTs inevitably involve the redistribution of water resources in relevant basins and may cause changes of the ecological environment in different basins. Such changes are two-sided, namely, the positive impacts, including adding new basins for waterdeficient areas, facilitating water cycle, improving meteorological conditions in the recipient basins, mitigating ecological water shortage, repairing the damaged ecological system, and preserving the endangered wild fauna and flora, as well as the negative impacts, including salinization and aridification of the donor basins, damage to the ecological environment of the donor basins and the both sides of the conveying channel system, increase of water consumption in the recipient basins, and spread of diseases, etc. Because IBTs have enormous ecological risk, it is necessary to comprehensively analyze the inter-basin water balance relationship, coordinate the possible conflicts and environmental quality problems between regions, and strengthen the argumentation of the ecological
\end{abstract}

Responsible editor: Philippe Garrigues

Wen Zhuang

wzhuang@yic.ac.cn

1 College of City and Architecture Engineering, Zaozhuang University, Zaozhuang, Shandong 277160, China

2 Key Laboratory of Coastal Environmental Processes and Ecological Remediation, Yantai Institute of Coastal Zone Research, Chinese Academy of Sciences, Yantai, Shandong 264003, China risk of water transfer and eco-compensation measures. In addition, there are some effective alternative measures for IBTs, such as attaching importance to water cycle, improving water use efficiency, developing sea water desalination, and rainwater harvesting technology, etc.

Keywords Inter-basin water transfer $\cdot$ Ecological environment $\cdot$ Ecological risk $\cdot$ Risk analysis .

Countermeasures

\section{Introduction}

Inter-basin water transfers (IBTs) mean building water transfer projects that span two or more basins for transferring water from a basin with abundant water resources to those in shortage, thus realizing adjusting water quantity between basins and resolving the water demand in the water-deficient area. The IBTs have developed over a long history. Dated back to the $2400 \mathrm{BC}$, as the Ancient Egypt intended to satisfy the demand for irrigation and shipping in today's south area of Ethiopia, King Menel commanded to build the first IBT project in the world, which diverted the water from the Nile to irrigate the land along the channel and eventually facilitated the development and prosperity of the Egypt civilization (Fang, 2005). However, modern IBTs emerged in the nineteenth century. So far, many countries around the world are facing the water shortage problem of different degrees. On March 21, 2013, Ban Ki-moon, the Secretary General of the United Nations, addressed on the World Water Day that it was predicted that there would be more than a half of the world population facing the water shortage problem by 2030 as the demand for water resources had exceeded by $40 \%$ of the water supply. Clean water source has become the significant restriction for the social and economic development of all 
countries. many countries have already employed large-scale and long-distance IBTs to redistribute water resources for alleviating the imbalance between supply and demand of water resources.

According to incomplete statistics, the IBTs which had already been completed or under construction around the world were totally more than 160 by 2015 , and dispersed in around 20 countries and regions, mainly including the USA, Canada, the former Soviet Union, India, Pakistan, and China, etc., all of which occupied over $80 \%$ of the total water transfer quantity (Yang, 2003; Wang et al., 2008; Zhao et al., 2015). Table 1 gives some world-renowned IBTs.

As the ecological and environmental problem becomes prominent day by day, people pay more attention to the ecological and environmental impacts of water transfer projects. IBTs appear to solve the problem of water shortage or full utilization of water resources. In contrary, after in-depth researches, it is found that the potential environmental and ecological impacts are gigantic and complicated (Wang, 1999). In general, such impacts include both direct and indirect, shortterm and long-term, evoked and accumulated, one-time and multiple. The paper takes a typical IBT case to introduce the ecological and environmental impact of the IBTs.

\section{China's South-to-North Water Transfer Project (SNWTP) with an uncertain future}

Known as the largest hydraulic project in the world, SNWTP is a national strategic project that aims to mitigate the water shortage problem in the north and northwest regions of China. It transfers abundant water from Yangtze River Basin to the north and northwest regions of China (Li et al., 2016). SNWTP is featured with large-scale, massive investment, involving a large number of participating parties and having significant impacts on the sustainable utilization of water resource in China. This mega project faces a number of complexity issues and challenges that had not been experienced in previous projects. (Liu et al., 2013). This project has three transfer lines, namely, the east line, the middle line, and the west line (Chen and Wang, 2012; Fig. 1). SNWTP commenced in 2003 and will take 50 years for completion; forty to fifty billion cubic meters of water are supposed to be delivered to northern China every year and benefit 300 to 325 million people (Zhao et al., 2015; Li et al., 2016). By December 2014, the accumulative investment had exceeded RMB 250 billion, $50 \%$ of the total planned investment (South-to North Water Diversion, http://www.nsbd.gov.cn/ zW/gg/201501/t20150119_366773.html).

The SNWTP has sparked a grievous controversy in environmental implication. On the one hand, the SNWTP is regarded as a unreliable water supply system because of its extensive energy demand. On the other hand, it has potential negative eco-environmental impacts such as water shortage and saltwater intrusion in water supply areas (Li et al., 2016).

Researchers pointed out that the Xiangfan section of Hanjiang River, as the water source of the middle line of the SNWTP, would have an evident water level drop after the commencement of the water transfer in the middle line, and the water pollution would aggravate and fish might decrease substantially (Li et al., 2015). Other researchers also considered that the estuary of the Yangtze River would suffer from a greater degree of salt water intrusion after the operation of the SNWTP. As a result, the drinkable water quality for Shanghai will be affected (Xu et al., 2012). The water donor basin of the east line of the SNWTP is located in the Yangtze River Delta where the industrial pollution is serious, the water conveyance canal passed through the Huaihe River Basin which is also polluted seriously. Therefore, water pollution is the main control factor restricting the economic benefits and development of the SNWTP (Gao and Wang, 2008).

The former Vice Minister of the Ministry of Housing and Urban-Rural Development of China claimed that the mode of water transfer for solving water shortage in cities of China had resulted in numerous problems, to a certain extent, it had "landed in a predicament" (Qiu, 2014): with the growing scale and distance of water transfer projects, it becomes more and more difficult to transfer water, and the ecological damage in the water donor basins becomes more and more serious; moreover, water transfer projects feature a lot of work, high investment and operation costs; in addition, because of the differences in terms of components between the transferred water and the local water, the scale deposit inside the tap water pipelines dissolves and separates out, which results in new pollution that cannot be treated easily (Qiu, 2014).

IBTs has complex ecological environmental impacts on water donor basins, water recipient basins, and area along water transfer routes. According to the nature, these impacts are divided into positive ones and negative ones which will be elaborated below. Measures adopted by experienced countries and strategies proposed by related researchers are illustrated to eliminate or reduce negative impacts on ecological environment caused by transfer project. Finally, several possible alternative measures of IBTs are introduced.

\section{Positive impact of IBTs on the ecological environment}

\section{Positive impacts on water donor basins}

IBTs which usually involves controlled comprehensive utilization of rivers can take advantage of abandoned water effectively to turn its harm into the good. Therefore, most of water transfer projects have flood control function. 


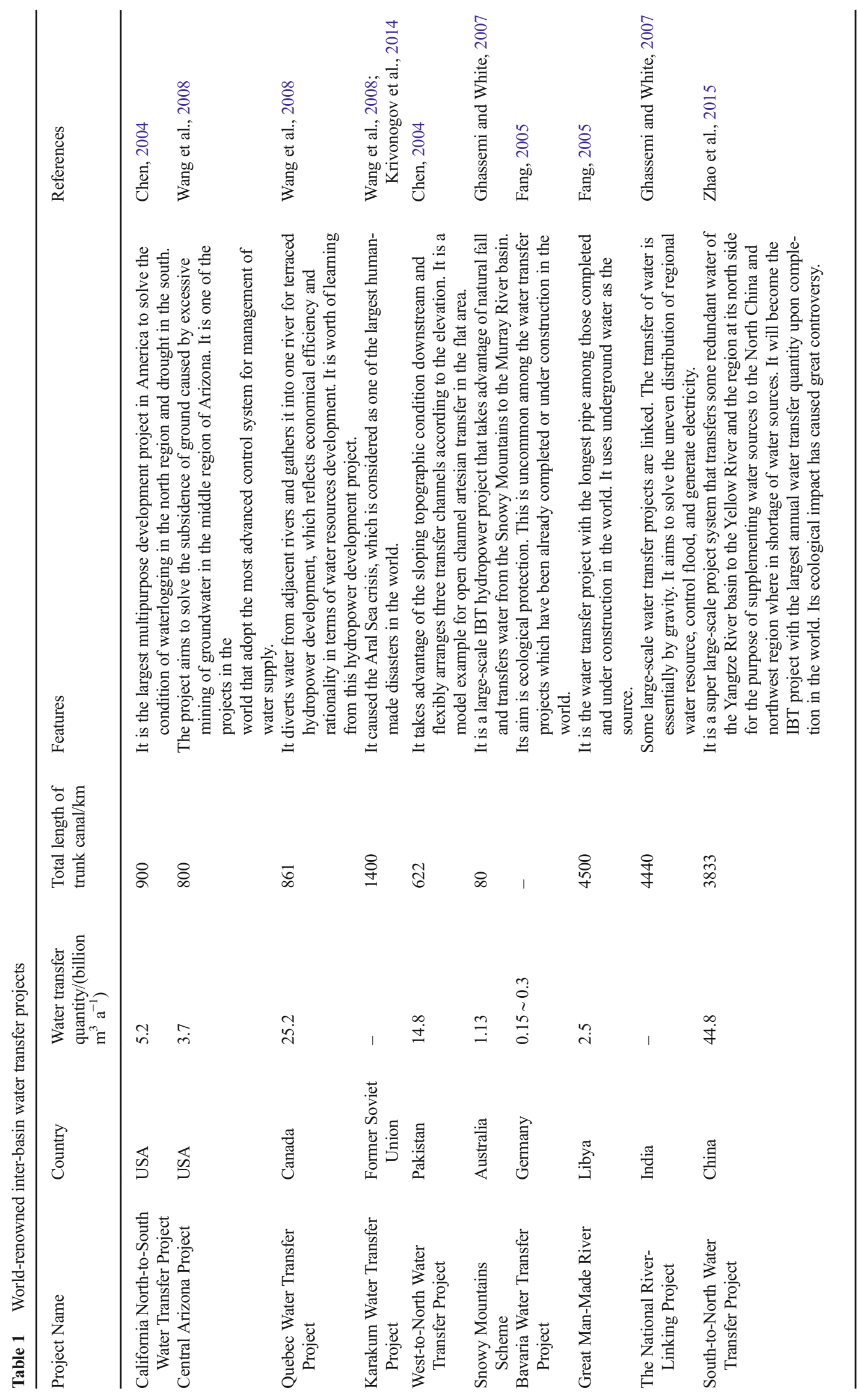


Fig. 1 Diagram of conveying lines of South-to-North Water Transfer project (The red dashed lines represent rivers; the deep yellow, green, and white dashed lines represent the three transfer lines; The yellow circles represent cities)

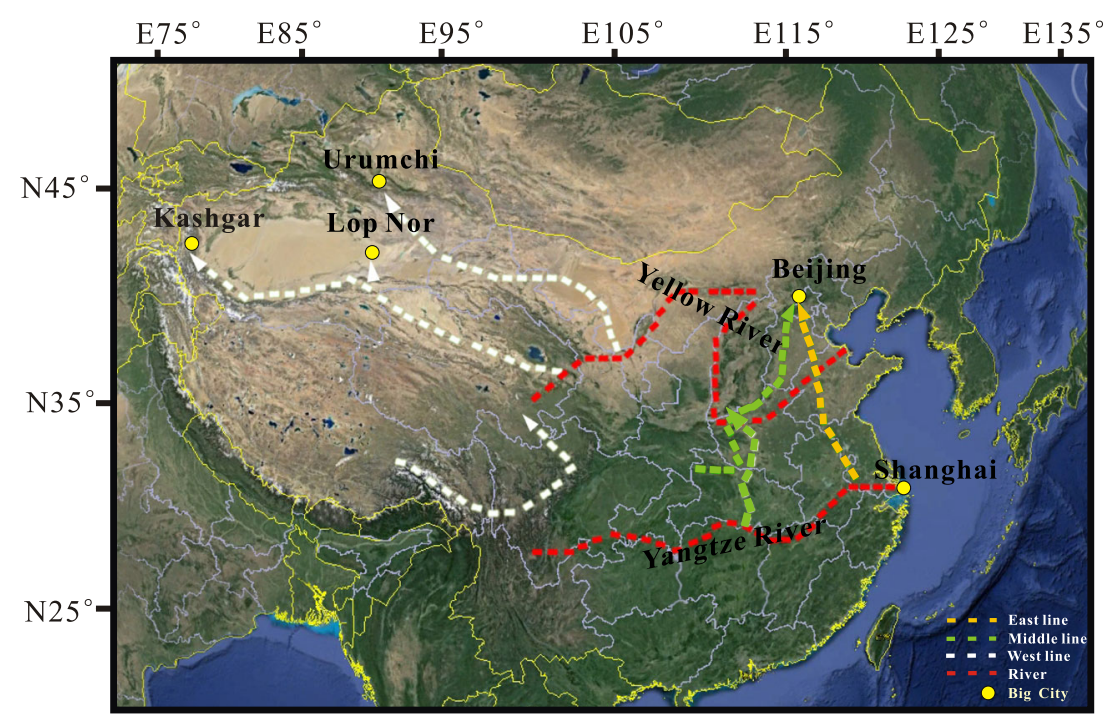

The distribution of precipitation is uneven in India, with maximum annual precipitation of $4000 \mathrm{~mm}$ in the eastern Himalayas and mountains of west coast, of $1000 \mathrm{~mm}$ in the eastern Assam, less than $600 \mathrm{~mm}$ in the leeward slope of the central and southern Ghats, and less than $100 \mathrm{~mm}$ in Rajasthan and Thar Desert in the northwest and in Gujarat in the north of Bombay where are the driest areas. Snow water supplied by Himalayas often causes flood in the north and the west, while monsoon rain causes short-lived flood in the south-central area (Wang, 2004; Ghassemi and White, 2007).

India has implemented a series of IBTs since the twentieth century. For example, Parambikulam Aliyar Project was built during the 1960s. It is a complex multipurpose project of seven streams consisting of five west and two east flowing rivers. These rivers were dammed and their reservoirs linked by tunnels. This project is used to irrigate 162,000 ha (Ghassemi and White, 2007). The Rajasthan Canal Project under construction which supplies water to the desert area from Himalayas has a supply canal $178 \mathrm{~km}$ in length with design flow of $685 \mathrm{~m}^{3} / \mathrm{s}$ and irrigated area of 1.2 million ha. The IBTs redistributed water resources rationally, which will play the role of irrigation in arid regions and can effectively reduce the flood disaster during the transfer (Wang, 2004).

\section{Positive impacts on water recipient basins}

\section{Restoration of the damaged ecological system and improvement of the biological diversity}

One of significant beneficial effects of IBTs is to restore the damaged ecosystems. As IBTs can increase more water areas for the water-deficient region, the vertical vapor exchanged among the hydrosphere, atmosphere, biosphere, and lithosphere intensifies accordingly. In addition, the water cycle benefits from it. And the meteorological conditions of the recipient basins are improved. IBTs may also increase the surface water supply and soil water content in the recipient basins, thus forming local wetlands, mitigating ecological water deficiency, compensating and regulating the water volume of rivers and lakes, as well as protecting the endangered wild fauna and flora (Dadaser-Celik et al., 2009; Rivera-Monroy et al., 2013; Wang et al., 2014).

The Mississippi is the primary water source for the coastal wetland in Louisiana. Affected by the large amount of projects along the river, the estuary inflow decreased day by day. The living environment of the coastal wetland was damaged and its ecological function degenerated gradually. In order to contain the degeneration of the wetland and recover its ecological function, the state government of Louisiana executed the Mississippi Transfer Project (Allisona and Meselhe, 2010). Meanwhile, the government also constructed relevant sand transfer project for the purpose of maintaining the stability of the estuary delta and wetland. The water and sand transfer projects effectively slowed down the disappearing estuary wetland (Lane et al., 2001; Snedden et al., 2007).

In 2000, China commenced the Peacock River Transfer Project to recover the wetlands ecosystem of Tarim River. It remarkably increased the underground water level in the recipient basin and supplemented the underground water within $1.05 \mathrm{~km}$ at both sides of the river. This project evidently improved the original degenerated wetland ecosystem, including the composition, varieties, distribution, and habitat for wetland plants, (Chen et al., 2008). In the same year, the Heihe River Water Transfer Project supplied water to East Juyanhai Lake, which had been dried for 10 years, continuously for 3 years from 2002 to 2004 . This has effectively contained the degeneration of the ecosystem and improved the biodiversity (Zhao, 2010). 
Relief of ground subsidence caused by overexploitation of groundwater

IBTs can reduce the exploitation of underground water and benefit the infiltration and capillary rising of the surface water, soil water, and underground water. Underflow discharge and other cycles are beneficial to the conservation of water and soil, and prevention of surface subsidence. From 1940, California over-exploited 1.8 million $\mathrm{m}^{3}$ of water every year with the exploitation depth of 305-754 m. Land subsidence affected farmland of more than $9000 \mathrm{~km}^{2}$. After water transfer, land subsidence was effectively prevented, and soil and water were conserved (Poland, 1981; Larsona et al., 2001).

\section{Improvement of water quality}

It can accelerate water exchange, improve self-purification capacity of water, and improve water quality through interbasin water transfer.

Although having more than $1900 \mathrm{~km}$ of coastline, Libya is a typical desert country with more than $95 \%$ of its area a desert. The vast majority of the population lives in the cities along the northern Mediterranean, with its capital Tripoli owns $28 \%$ of the population. Shortage of fresh water cannot be solved only through desalination, since groundwater in coastal areas has been depleted and the water is not suitable for drinking because of the penetration of seawater (Gijsbers and Loucks, 1999).

Libya began to build an underground artificial river in the desert to supply water to the north. The project is planned to be finished in 30 years with total investment of USD $\$ 30$ billion. It is designed to pump groundwater of 6.5 million cubic meters per day from Kufra, Tāzirbū, Sabha, and other oases in the south, and transport the water to Ajdabiya reservoirs in the north through the underground cement pipelines of total length of $5000 \mathrm{~km}$ and the diameter of $4 \mathrm{~m}$ and multi-stage pump stations along, in order to meet industrial and residential water consumption and farm irrigation of 400,000 ha in the north coast. In addition to meeting municipal water consumption, the national food self-sufficiency rate reached $40 \%$ since 250,000 ha of farmland was irrigated and a number of large farms had been established by water transfer (http://global. britannica.com/topic/Great-Man-Made-River).

\section{Positive impacts on the water transfer routes}

Through water transfer, the nutrients are brought into the water, which is conducive to growth and reproduction of food organisms and fish and promote the development of fishery. Furthermore, it can also improve water quality, expand waters, so that to create artificial and ecological landscape and develop tourism, entertainment and so on.
Pakistan further improved the irrigation system in Indus plains and gradually restored and developed water supply to irrigation system in the Ravi River, Sutlej River, and Beas River through its construction of West-to-East Water Transfer Project. According to statistics from 1971 to 1978 , the quantity of water transfer which is transported from the Indus River and its tributaries Jhelum River and Chenab River to the Ravi River, Sutlej River, and Beas River has been accumulated to 152.4 billion $\mathrm{m}^{3}$, with an annual average of 21.8 billion $\mathrm{m}^{3}$ and irrigated farmland of 1.63 million ha. Pakistan transforms from the original food importing country to an exporting one since its agricultural production conditions have been greatly improved. Habitat is provided for endangered wildlife along the water transfer route, and dams and channels also become scenic tourist area (Li et al., 2003).

\section{Negative impacts of IBTs on the ecological environment}

IBTs are double-edged swords. Apart from the positive impacts on the ecological environment, IBTs also have the negative impacts. One of the major features of the IBTs is the redistribution of water resources. But, they will cause some ecological environmental risks. By summarizing the collected data, the primary negative impacts of IBTs for the ecological environment are given as below:

\section{Negative impacts on water donor basins}

Large-scale and long-distance IBTs might not only cause the decreasing runoff volume of the water donor rivers, but also might result in salinization of soil and salt water intrusion at the estuary.

The North-to-South Water Transfer Project of the former Soviet Union, transferring water from Neva River, caused the decreasing water volume of the Lake Ladoga. Because of this, inorganic salt and mineralized debris increased, and finally the ecological system was seriously damaged. Although methods have been taken in recent years to reduce the content of inorganic salt flowing into the lake, they haven't achieved the anticipated goal of ecological recovery (Pozdnyakov et al., 2013).

Another example: the California Water Transfer Project and the Delta Mendota Canal of the Central Valley Project reduced the fresh water flowing into the San Francisco Bay from the Sacramento River and San Joaquin River by $40 \%$. The water quality of the San Francisco Bay thus deteriorated and sea water intruded into the delta, forming a salinity gradient about $80 \mathrm{~km}$ long that extends from the western part of the Delta downstream to northern San Francisco Bay (Davies et al., 1992; Ma and Wang, 2011). 


\section{Negative impacts on water recipient basins}

\section{Causing the waste of water resources in recipient basins}

IBTs might stimulate the water consumption in recipient basins, thus it had to increase water transfer endlessly. What is more, the extensive irrigation method and predatory agricultural operation resulted in the salinization of a large amount of land. More seriously, the unexpected increase of water consumption lead to reduction of runoff into the sea. The quantity of water consumption is related to the local climatic conditions, situations of water use and ways of water use. Except the climatic conditions, the other two items are directly connected to human activities. It is estimated that the evaporated water around the world increases approximately 8.7 trillion $\mathrm{m}^{3}$ every year owing to the activities such as reservoir storage, water transfer projects, agricultural cultivation improvement of irrigated and non-irrigated land. In addition, 150 billion $\mathrm{m}^{3}$ of water evaporated by cities and industries. It totals around 8.85 trillion $\mathrm{m}^{3}$, which is equivalent to the daily increase of 24 billion $\mathrm{m}^{3}$, almost equal to $2 \%$ of the evaporated water from the earth surface or $12 \%$ from the land (Chen, 2004).

\section{Spread of new pollution and diseases}

IBTs usually feature long-distance water delivery line that crosses regions with complex ecological geographic characteristics. This may cause diseases such as typhoid fever, dysentery, cholera, encephalitis, and bilharziasis, which affect the human health (Sible et al., 2015). Excessive water transfer for irrigation may easily generate and spread parasite and aquatic organism diseases that are particularly serious in the tropics and subtropics. For example, the Orange River Water Transfer Project in South Africa was taken for irrigation and domestic use along the channel, thus the incidence of schistosomiasis expanded and increased with the agricultural development, schistosomiasis host snails, and a corresponding increase in population density (Gupta and van der Zaag, 2008).

IBTs may also bring the contaminants of the water source or along the channel to the recipient basins. Lake Michigan Water Transfer Project (Chicago, USA) is one of the earliest and most controversial IBTs, since it has a long history of suffering from various kinds of contaminants such as persistent organic pollutants (Murphy and Rzeszutko 1977; Delfino, 1979; Rasmussen et al., 2014).

\section{Negative impacts on the water transfer routes}

\section{Salinization on both sides of the conveying channels}

The early water transfer projects which existed with problems of water loss and evaporation in water distribution system were mostly constructed for the purpose of irrigation. The lack of supporting drainage systems or unreasonable design of drainage systems will cause accumulation and redistribution of salt in the soil once the soil water table is higher than the critical depth of groundwater. Accordingly, the saline concentration will build up in the crop root layer. As a result, the soil structure is damaged, nutrient elements are lost, and water-soil and water-salt balance are broken. Eventually, negative influences are brought to the ecological environment (Zhao et al., 2008; Liu et al., 2013).

West-to-East Water Transfer Project of Pakistan has three irrigation channels, totaling $663 \mathrm{~km}$, with artesian transfer speed of $1493 \mathrm{~m}^{3} \mathrm{~s}^{-1}$. Its water level is averagely $1 \mathrm{~m}$ higher than the banks. Thus, seepage water supply to the underground water even reaches $3.5-4.5$ billion $\mathrm{m}^{3} \mathrm{a}^{-1}$. For this reason, several hundreds of meters wide along the banks become swampy. Moreover, owing to the insufficient drainage, the turnover of water quantity in this region is extremely imbalanced, which results in land waterlogging and soil salinization, as well as destruction of fertility and crop failure. More than 24,000 ha of cultivated land is affected every year (Ma and Wang, 2011).

\section{The effects of the open canal on migration routes and animal mortality}

The open nature of the canal might act as an animal trap, which is one of the most contentious, emotive, and serious impacts of the water transfer canal (Davies et al., 1992).

An estimate of the death toll for $65 \mathrm{~km}$ of the canal of the Eastern National Water Carrier (Namibia) between June 1985August 1986 revealed a total of 7234 vertebrates (excluding decomposed animals, and those consumed by carrion feeders). Nearly 30 mammal species were recorded, including aardwolf, rare pangolin, antbears, and bat-eared fox. Of the total, $57 \%$ were reptiles, $22 \%$ amphibians, $19 \%$ mammals, and $2 \%$ were birds. Certain endangered species, such as the Cape Vulture, Gyps coprotheres might have also been fall prey to the canal when feeding on large game which has drowned (Davies et al., 1992).

\section{Negative impacts on the original water recipient basins}

\section{A typical case is the Amu Darya and Syr Darya Transfer Projects and the drought of the Aral Sea}

The Aral Sea, located at the junction of the Republic of Kazakhstan and the Republic of Uzbekistan, is an internal salt water lake, which once was the fourth largest fresh water lake in the world (Kristopher, 2013; Fig. 2). The water source for the Aral Sea mainly comes from Amu Darya and Syr Darya. In 1960, the gross area of the Aral Sea reached $67,500 \mathrm{~km}^{2}$. The average depth was $54 \mathrm{~m}$. And total water volume was 1.09 trillion $\mathrm{m}^{3}$. Hundreds of kinds of fished lived in the Aral Sea. It offered more than ten thousand tons of fishes product every year which provided sufficient food for the 


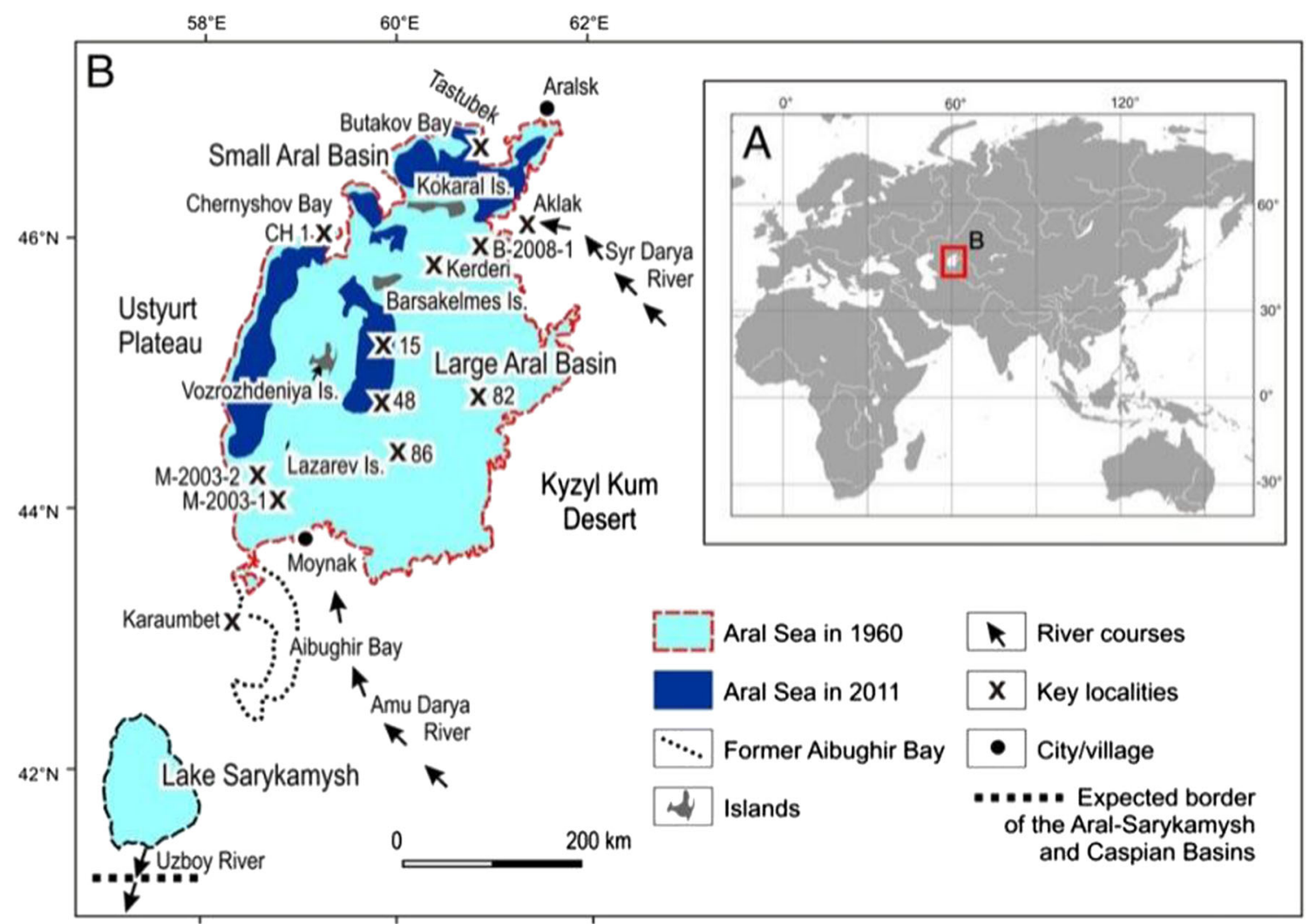

Fig. 2 The position of the Aral Sea (quoted from Krivonogov et al., 2014)

residents living by the Lake. The large water body of the Aral Sea also regulated the dry climate in the Central Asia.

It took only 50 years to drain the Aral Sea. And the primary reason behind this is some large-scale water transfer projects implemented by the former Soviet Union. In the 1930s, the former Soviet Union planned to develop irrigation agriculture in the Central Asia. However, the priority problem to be solved was water source. Syr Darya from Tianshan Mountains and Amu Darya from Pamirs became the primary water source for this plan. The two rivers flew across the five primary Former Soviet Republics in the Central Asia, namely, Tajikistan, Kyrgyzstan, Uzbekistan, Kazakhstan, and Turkmenistan, and finally flew into the Aral Sea (Kristopher, 2013).

In 1937, the Grand Figuera Canal of $220 \mathrm{~km}$ was built from Syr Darya. In 1954, Karakum Water Transfer Project officially commenced with the goal to divert the natural channels of Amu Darya and Syr Darya to the east Turkmenistan and middle Uzbekistan for irrigation. In this period, the Karakum Lenin Canal was dug with a total length of $1400 \mathrm{~km}$. It started from the upstream Amu Darya to irrigate the west Turkmenistan. In 1960, a total of 6.6 million ha of cotton field and paddy field were reclaimed in the basin of Amu Darya, Syr Darya, and the newly dug canals. It became the new grain and cotton production base for the former Soviet Union.

Regardless of this, the substantial increase of economic benefits could not cover the fact of the rapidly deteriorating natural environment (Aladin and Potts, 1992; Whish-Wilson, 2002; Glantz, 2004; Small et al., 1999, 2001; Vostokova, 2004; Roy et al., 2014). The water sources for the Aral Sea were Amu Darya and Syr Darya. As the water transfer project introduced water from the two rivers for irrigation on a large scale, the water volume flew into the Aral Sea decreased sharply (Fig. 3). Before the construction of the water transfer project in the 1960s, the average water volume flowing into the Aral Sea was 56 billion $\mathrm{m}^{3}$. It decreased to 26 billion in the 1970s; 7 billion at the beginning of the 1980s; and almost zero at the end of the 1980s. Without any water supplement and owing to the high amount of evaporation, the Aral Sea had a constantly decreasing water quantity and rapidly shrinking lake surface area. The salt concentration increased to triple times of that of the sea water, which made massive mortality of fish and aquatic organism as well as degeneration of biotic population. By 2020, salinity of the Aral Sea may increase up to $237-250 \%$ (Rafikov and Gulnora, 2014).

The massive grain and cotton production and large number of immigrants in the 1970s and 1980s generated a large amount of irrigation and domestic wastewater with plenty of residual chemical fertilizer and pesticide. When such wastewater flew back to the Amu Darya and Syr Darya and finally to the Aral Sea, it polluted the water of the Aral Sea. After the Aral Sea dried up, the salt and alkali at the lake bottom were exposed. Tens of thousands of poisonous salt and alkali 
Fig. 3 LANDSAT images showing the spatial extent of the Aral Sea in a the 1970s, b summer of 1999, and $\mathbf{c}$ summer of 2011, respectively (Roy et al., 2014)
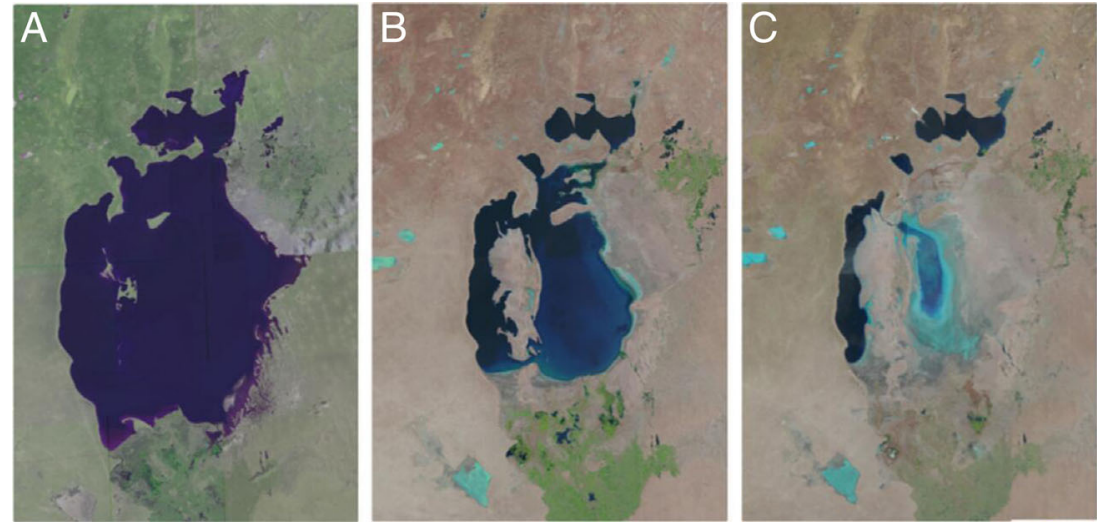

compounds are blown up from the dried seabed every year, forming the "salt sand storm" from north to south, which aggravates the salinization and desertization in the Central Asia. $80 \%$ of the cultivated land in the Republic of Turkmenistan has had a high level of salinization. The increasing amount of salt and harmful matters also threaten the health of local residents. It shows an evident increase of percentage of developing diseases such as leukemia, nephropathy, and trachitis. What is more serious is that the precipitation in the Central Asia is decreasing year by year owing to the absence of the regulation by the Aral Sea for the local climate, thus resulting in continuous drought. The average temperature in summer rises with each passing year while it drops remarkably in winter. The season for growth becomes shorter and shorter (O'Hara et al., 2000a, b; Wiggs et al., 2003). All the benefits acquired in the past decades in the Aral Sea basin by the former Soviet Union is far from compensating the consequences of ecological disasters in this basin.

\section{Countermeasures against the negative ecological impacts of IBTs}

\section{Enhancing risk evaluation on the eco-environmental risks of IBTs}

IBTs are grant projects to transform nature, since they cover a wide range with a great amount of investment and arduous projects. In addition, this may bring long-term issues to the society and ecological environment. Comparing with other water conservation measures like construction of aboveground and underground reservoirs, water saving, and treatment and recycling of effluent sewage, IBTs involve more issues. And, in most cases, "the distant water cannot quench present thirst". Therefore, an IBT project shall only be finalized and implemented after carrying out comprehensive feasibility study and evaluation of rationality and legitimation regarding the scale, benefits, ecological environment, society, and other aspects, as well as careful planning and design (Wen et al., 2011; Locatelli et al., 2014; Zhao et al., 2015). Otherwise, another way should be taken.

Davies et al. (1992) appealed that research should address not only a comprehensive approach to measuring the ecological impacts of IBTs, but also the evaluation of the ecological risks associated with them, as well as the development of monitoring programs which will allow alterations to be made to operational criteria, such that particularly deleterious impacts may be reduced. Davies et al. (1992) also urged that an international workshop be conducted to address the lack of knowledge of the ecological impacts of IBTs, their extent and distribution, and the development of a suitable ecological ethic, monitoring programs, and the integration of IBTs into overall catchment planning and management.

Based on a comparative assessment of the different disciplinary, political, and legal approaches to evaluating whether IBTs can be justified, Gupta and van der Zaag (2008) proposed five criteria to evaluate inter-basin transfer schemes in the context of Integrated Water Resources Management:

1. Real surplus and deficit: there is a real (objectively verifiable) surplus in the donor basin; and there is a real (objectively verifiable) deficit in the recipient basin where water is used efficiently (with the best available technology).

2. Sustainability: the transfer scheme is designed to be sustainable in terms of social, environmental and economic aspects, and is adaptive to natural and social stresses.

3. Good governance: the scheme is based on good governance (including participatory decision-making and accountability to the public).

4. Balance existing rights with needs: the transfer scheme respects existing (local, national and international) rights, and responsibilities; without negative extra-territorial effects and other impacts on riparian countries. If such impacts nevertheless do occur, adequate compensation measures or benefit sharing have been agreed. No person or family or community or state will be worse off because of the scheme. 
5. Sound science: the scheme is based on sound science, including hydrological, ecological, and socio-economic analyses. It adequately identifies uncertainty and risk, and gaps in knowledge. All possible alternatives have been considered.

Gupta and van der Zaag (2008) laid special stress on that in applying the proposed set of criteria to evaluate inter-basin transfer schemes, the overall strength of a particular scheme will be determined by the criterion that scores lowest, much like the strength of a chain being determined by the weakest shackle.

The Indian government is doing a good job in strengthening the ecological environmental impact of water transfer. Although a large-scale development has been made for irrigation water source in recent decades, the Indian government and the state governments are still making plans and doing researches for a long distance and large flow water transfer. The Indian government has recognized the importance of large-scale water transfer for the development of water resources and the improvement of the environment (Gupta and van der Zaag, 2008).

\section{Developing and improving the relevant laws and regulations, and enhancing government surveillance and management}

Policies and regulations provided a guarantee for the normal operation scheduling of water transfer project. Successful water transfer projects are basically developed relevant laws and regulations.

In the USA, construction of water transfer projects is proceeded strictly in accordance with relevant regulations from the project approval, determination of investment scale to construction management and the repayment of project investment. A project invested and constructed by federal or state government always has a corresponding specific bill. Effective legislation and strict enforcement provided an important guarantee for the success of the USA in water conservancy construction and water resources allocation projects. From the date of approval, the construction of a water transfer project is guaranteed by law from aspects of water allocation, investment, quality standards, benign operation and management mechanism and benefit development after completion.

The US federal government provided legislative protection for California North-to-South Water Transfer Project (Gill et al., 1971). After the completion of project design, the California State Assembly determined the construction and management framework in legal form, and decided that the full construction costs of the project was derived from bonds and loans which would be repaid by operating income from the project. Another Example: The US federal government adopted the Act for Colorado River Basin Project for Central
Arizona Water Transfer Project, and authorized the Bureau of Reclamation to fund and construct the project. The government defined tasks of the project, including transporting water from the Colorado River to Central Arizona and returning funds for the construction of Central Arizona Water Transfer Project invested by the federal government (Wang et al., 2008).

\section{Establishing systems for restoration and compensation to re-establish the integrity of ecosystems}

In the execution stage of the water transfer works and the later stage of water transfer, eco-compensation measures of ecological restoration and ecological compensation are also essential.

Successful IBTs are basically equipped with many regulating reservoirs along the route and established with stable bases for water resources, so that to provide the fundamental guarantee for the redeployment of water resources. The functions of regulating reservoir are to store excess water during the rainy season and reasonably control discharge volume for the river in order to ensure the balance of surface water and groundwater in both the water resources area and the intake area. It also helps to prevent excessive exploitation of groundwater in dry season and low flow year and make comprehensive utilization of surface water and groundwater.

The most successful experience of California North-toSouth Water Transfer Project is to store excess water in 20 reservoirs in the delta region and then transport it to different places by canals. Throughout the entire water transfer project from north to south, rational layout of large reservoirs guaranteed water supply. Central reservoirs saved surplus water at any time to facilitate the redistribution of water resources, while adjustment by many reservoirs along the way effectively improved the guarantee rate of water supply (Wang et al., 2008). Composed by 16 reservoirs and related buildings, Australia Snowy Mountains Scheme transports water of 1.13 billion $\mathrm{m}^{3}$ per year to inland. During the drought, adequate released water and proposed irrigation water are guaranteed by adjustment of large reservoirs, in order to make sure the quantity of water transfer is not less than $85 \%$ of the average flow rate even in the worst periods (Ghassemi and White, 2007; Wang et al., 2008).

Pakistan develops water conservancy projects very early and becomes one of the countries doing well in irrigation and drainage. Pakistan West-To-East Water Transfer Project was once encountered with the problem of salinized channels because the conveying channels and intake region suffered a large amount of seepage to supplement the underground water, particularly in the high level water delivery sections. Later, the Salinity Control and Reclamation Project came into effect: on the one hand, it lowers the underground water lever by hydraulic measures; on the other hand, it prevents and treats land waterlogging and salinization by crops and soil improvement and other measures. Twenty years since the adoption of 
the this project, good results have been obtained (van Steenbergen and Oliemans, 2002).

The Dongshen Water Supply Project of China, which is located within Shenzhen and Dongguan in Guangdong Province, and aims to supply water to Hong Kong, Kowloon, and Shenzhen Special Economic Zone. In order to conserve water sources, ecological public welfare forest was planted in water sources and on both sides of Dongjiang. It is a great economic loss for farmers once the forest is classified as ecological public welfare forest which cannot be cut and plant economic forest. Therefore, the Chinese government and the Guangdong provincial government have established the compensation mechanism for ecological benefits of forest, so that to compensate farmers for economic loss by means of financial transfer payments (Zhang, 2012).

\section{Preventing and controlling of water pollution}

The water quality may continuously suffer cumulative and sudden impacts caused by land development and man-made pollution in the water basin. The higher the rate of urbanization is, the worse the water quality in this basin will be. Governments should adopt effective measures to protect the water environment in order to give better play to the long-term benefits of project.

After completion of Australia Snowy Mountains Scheme, the Australian government adopted a series of effective measures to protect the water environments (Liu, 2000):

1. Strictly control the growth of agricultural water consumption. Related state government has reached a consensus that the government will no longer issue new agricultural water permit and significantly increase the price of water. The government will strictly restrict the increase of agricultural water consumption, encourage investment in updating irrigation technology, and limit to draw water from river to ensure that there is enough flow to flush off salt.

2. Strengthen overall work on water and soil conservation. There are many reservoirs in water supply system of Snowy Mountain Scheme. In order to ensure that these water storage projects are free from the threat of siltation, the federal government developed the water area of Snowy Mountain Scheme as a national park which is a tourism attraction without the development of other industries. Tourists can only walk on a particular passage which is actually a small wooden bridge above the ground in order to protect the vegetation.

3. Appeal to the whole society to protect water quality consciously. In Australia, the key points of water quality protection are to prevent the outbreak of blue-green algae and agricultural sewage flow into the river. The effective means to prevent the growth of blue-green algae is to reduce organic matter enter into the water; therefore, intercepting plates are built along the banks in order to prevent leaves and hay to be involved in the water and untreated sewage is strictly forbidden from being discharged into the river. Nowadays, states have already regarded water transfer and construction of sewage treatment as a whole, and areas with large processing capacity will get preferential treatment in the water supply.

Germany is one of the countries who did better in water environment protection. According to the German Water Management Act, water protection areas can be set in necessary places and implement with special requirements and prohibitions in order to avoid being damaged. Residential and industrial buildings are not allowed to be built in more stringent protection zone, while specified business, sewage treatment plants and transport routes can be established according to the provisions in lesser degree of protection areas; however, gas stations and chemical warehouses which shall be harmful to the water sources are not allowed to be constructed and operated (DVGW 1975a, b). For example, in order to protect Bodensee, German local government established water conservation areas around the lake to prevent water pollution and damage of water quality, and formulated regulations for protection areas to specify the list of activities permitted and prohibited in the protection zone.

\section{Effective alternative measures for IBTs}

\section{Developing water cycle and improving water use efficiency}

As to the concept of development, first of all, applicable cutting-edge technologies should be integrated with measures like safe use of water, wastewater treatment and recycling, energy recovery and utilization, and rainwater harvesting and recycling, etc. Secondly, we should transform from large-scale transfer and drainage to ecological restoration, as well as from water transfer for flushing and diluting pollution to restoration of the local water self-purification function and the water ecology. Thirdly, we should transform from the former unscientific mode of water use (demand-decided model) to the water-saving mode (supply-decided model). Lastly, we should transform from extensive development to healthy recycling of water resources.

New York was in severe shortage of water resources in the 1960s. The initial solution was to transfer water from New Jersey. The project budget exceeded USD $\$ 10$ billion. Considering such enormous investment and the disagreement of New Jersey residents on the water transfer solution to New York, this project was not executed. As New York was stuck in this predicament, experts in the field of urban drainage put 
forward a piece of advice - replacing all the old flush toilets in New York with water-saving flush toilets $(6 \mathrm{~L} /$ flush $)$ and providing subsidy of $20 \%$ of the replacement costs for each toilet by the government. This proposal was adopted by New York. After all the toilets were replaced in 11 years with a total investment less than USD\$300 million, the daily water consumption per capita dropped by $14 \%$. Finally, the water crisis was solved with results that could not be realized by the USD\$10 billion water transfer project (Qiu, 2014).

Rainwater outflow restraining technology has a promising future. A key reason for water shortage is the extremely unbalanced space-time distribution of water resources. In many regions a large amount of fresh water flows to the sea in the wet season owing to the absence of sufficient storage facilities, and even causes urban flooding. Therefore, it will be a development direction for the study of water issues in cities by utilizing the underground storage facilities to store water resources and rainwater and regulating rainwater, in addition to the storage by rivers and reservoirs. For example, Japan has built underground artificial rivers and reservoirs in many metropolises for the purpose of regulating the rainwater outflow and storing the excess natural rainfall in wet seasons for the use of dry seasons and improving the situation of water shortage (An et al., 2015; Imteaz et al., 2015; Ste and Kordan, 2015).

\section{Sea water desalination}

Sea water desalination has a promising future. The coastal regions and islands in serious shortage of water may take advantage of membrane technology to desalinate sea water and thus solve the problem of water source. The desalinated sea water can be used in municipal water supply and industrial water use, particularly for the electronics industry with high demand for water quality. Good benefits have been obtained. However, comparing with wastewater recycling, sea water desalination has evident drawbacks. Firstly, the range of application is small. Secondly, the construction and operation costs are more than two times of that of the wastewater recycling. Thirdly, the application region is limited. It is only suitable for coastal regions, but wastewater recycling almost has no geographic restrictions.

These are still large issues that are provoked by IBTs. This article would not perhaps answer all of the questions. What it will do is to critically review some approaches that have been proposed for the integrated or holistic assessment of such large man-made projects.

\section{Conclusions}

In general, each way of water transfer will quickly change the water-deficient situation, improve the geological environment, and facilitate social and economic development in the recipient basin. That is what people expect, regardless of the negative impacts, which may be ignored. Although large-scale long-distance IBTs do not affect the entire hydrosphere and its interchange of material and energy flow with the atmosphere, biosphere, and lithosphere, but it will affect the regional, territorial ones and break the original relative balances and establish new relative balances. Moreover, the longer the distance and the larger the scale of water transfer projects are, the heavier the influence will be. And the influence factors are more complex, comprehensive, and ecological. Despite that it is still not clear about the effect and impacts of most water transfer projects on the geological environment and relative balance so far, we should not treat it lightly.

Essentially, water transfer is to "rob Peter to pay Paul" —an "addition" of water resources between different regions, while water recycling is a "multiplication". Through water recycling, a substantial amount of long-distance water projects can be replaced effectively. Plus sea water desalination, rainwater harvesting and utilization of other non-traditional water resources, a majority of cities in the world are capable of solving their own problem of water shortage. Therefore, during planning and design of IBTs, we should fully consider impacts of the project on the society, economy and ecological environment, and conduct overall planning so as to realize the maximum comprehensive benefits. Otherwise, another way should be taken.

Acknowledgments This study was co-supported by the Natural Science Foundation of Shandong Province, China (ZR2014DP005) and the Research Fund for the Doctoral Program of Zaozhuang University, China (2014BS11). I appreciate the Editor Dr. Philippe Garrigues and anonymous referees, whose constructive comments allowed me to improve the manuscript. My sincere gratitude also goes to my wife Qian Wang who did a lot of the translation work for the manuscript.

\section{References}

Aladin NV, Potts WTW (1992) Changes in the Aral Sea ecosystem during the period 1960-1992. Hydrobiologia 237:67-79

Allisona MA, Meselhe EA (2010) The use of large water and sediment diversions in the lower Mississippi River (Louisiana) for coastal restoration. J Hydrol 387(3-4):346-360

An, K.J., Lam, Y.F., Hao, S., Morakinyo, T.E., Furumai, H., 2015. Multipurpose rainwater harvesting for water resource recovery and the cooling effect. Water Res. In Press, doi:10.1016/j.watres.2015.07.040.

Chen YH (2004) Analysis on advantages and disadvantages of large scale, long distance and transbasin diversion. Water Resour Prot 59(2):48-50, In Chinese

Chen YN, Pang ZH, Chen YP, Li WH, Xu CC, Hao XM, Huang X, Huang TM, Ye ZX (2008) Response of riparian vegetation to water-table changes in the lower reaches of Tarim River, Xinjiang Uygur, China. Hydrogeol J 16(7):1371-1379

Chen ZS, Wang HM (2012) Optimization and coordination of South-toNorth Water Diversion supply chain with strategic customer behavior. Water Sci Eng 5(4):464-477 
Dadaser-Celik F, Coggins JS, Brezonik PL, Stefan HG (2009) The projected costs and benefits of water diversion from and to the Sultan Marshes (Turkey). Ecol Econ 68(5):1496-1506

Davies BR, Thoms M, Meador M (1992) An assessment of the ecological impacts of inter-basin water transfers, and their threats to river basin integrity and conservation. Aquat Conserv 2(4):325-349

Delfino JJ (1979) Toxic substances in the Great Lakes. Environ Sci Technol 13:1462-1468

DVGW (German Association for Gas and Water) (1975a) Guidelines for drinking water protection areas, Part II: protected areas for drinking water reservoirs (= DVGW- worksheet w 102). Version 2. DVGW, Eschborn, In German

DVGW (German Association for Gas and Water) (1975b) Guidelines for drinking water protection areas, Part III: protected areas for lakes (= DVGW- worksheet w 103). DVGW, Eschborn, In German

Fang Y (2005) Inter-basin water diversion projects abroad and the corresponding eco-environment influences. Yangtze River 36(10):9-10, 28. (In Chinese)

Ghassemi F, White I (2007) Inter-basin water transfer: case studies from Australia, United States, Canada. Cambridge University Press, China and India

Gijsbers PJA, Loucks DP (1999) Libya's choices: desalination or the Great Man-made River Project. Phys Chem Earth Pt B 24:385-389

Gill GS, Gray EL, Seckier D (1971) The California water plan and its critics, a brief view//Seckier, D., California water: a study in resource management, Gill G.S, Gray E.L, Seckier D. University of California Press, Berkeley

Glantz MH (2004) Sustainable development and creeping environmental problems in the Aral Sea region. In: Glantz MH (ed) Creeping environmental problems and sustainable development in the Aral Sea region. Cambridge Univ. Press, Cambridge, UK, pp 1-25

Gao L, Wang JT (2008) Impacts of the South-to-north Water Transfer Project on ecological environment. Water Conserv Sci Techn Econ 14(2):131-133 (In Chinese)

Gupta J, van der Zaag P (2008) Interbasin water transfers and integrated water resources management: where engineering, science and politics interlock. Phys Chem Earth 33(1):28-40

Imteaz MA, Paudel U, Ahsan A, Santos C (2015) Climatic and spatial variability of potential rainwater savings for a large coastal city. Resour Conserv Recy 105(Part A):143-147

Kristopher DW (2013) Nature-society linkages in the Aral Sea region. J Eurasian Stud 4(1):18-33

Krivonogov SK, Burr GS, Kuzmin YV, Gusskov SA, Kurmanbaev RK, Kenshinbay TI, Voyakin DA (2014) The fluctuating Aral Sea: a multidisciplinary-based history of the last two thousand years. Gondwana Res 26:284-300

Lane RR, Day JW Jr, Kemp GP, Demcheck DK (2001) The 1994 experimental opening of the Bonnet Carre Spillway to divert Mississippi River water into Lake Pontchartrain. Louisiana Ecol Eng 17(4):411422

Larsona KJ, Başağaoğlu H, Mariño MA (2001) Prediction of optimal safe ground water yield and land subsidence in the Los Banos-Kettleman City area, California, using a calibrated numerical simulation model. J Hydrol 242(1-2):79-102

Liu JG, Zang CF, Tian SY, Liu JG, Yang H, Jia SF, You LZ, Liu B, Zhang M (2013) Water conservancy projects in China: achievements, challenges and way forward. Global Environ Chang 23:633-643

Liu (2000) Selection of Overseas Water Resources and Hydropower Investigation and study reports by Ministry of Water Resources. Haichao Press, Beijing, In Chinese

Li XR, Zhang MZW, WenM LL (2015) Study on water resources carrying capacity in Xiangyang City based on Middle route of China's south-to-north water diversion project. Environ Monit Assess 6: 121-128 (In Chinese with English abstract)

Li YH, Chen XG, Shen YS (2003) West-to-East water diversion project in Pakistan. Water Resour Dev Res 1:56-58 (In Chinese)
Li Y, Xiong W, Zhang WL, Wang C, Wang PF (2016) Life cycle assessment of water supply alternatives in water-receiving areas of the South-to-North Water Diversion Project in China. Water Res 89:919

Locatelli G, Mancini M, Romano E (2014) Systems engineering to improve the governance in complex project environments. Int J Proj Manag 32(8):1395-1410

Ma FB, Wang X (2011) Impacts of water transfer project on eco-environment: a review. Water Conservancy Sci Technol Economy 17(10): 20-24 (In Chinese)

Murphy TJ, Rzeszutko CP (1977) Precipitation inputs of PCBs to Lake Michigan. J Great Lakes Res 3:305-312

O'Hara SL, Wiggs GFS, Mamedov B, Davidson G, Hubbard RB (2000a) Exposure to airborne dust contaminated with pesticide in the Aral Sea region. Glob Planet Change 355:627-628

O'Hara SL, Wiggs GFS, Mamedov B, Davidson G, Hubbard RB (2000b) Exposure to airborne dust contaminated with pesticide in the Aral Sea region. Lancet 355:627-628

Poland JF (1981) The occurrence and control of land subsidence due to ground-water withdrawal with special reference to the San Joaquin and Santa Clara Valleys, California, Ph.D Thesis. Stanford University, USA

Pozdnyakov DV, Korosov AA, Petrova NA, Grassle H (2013) Multi-year satellite observations of Lake Ladoga's biogeochemical dynamics in relation to the lake's trophic status. J Great Lakes Res 39:34-45

Qiu BX (2014) The urban water security situation and the countermeasures at present in China. Water Supply Drain 40(1):1-7 (In Chinese)

Rafikov V, Gulnora M (2014) Forecasting changes of hydrological and hydrochemical conditions in the Aral Sea. Geod Geodyn 5(3):55-58

Rasmussen PW, Schrank C, Williams MCW (2014) Trends of PCB concentrations in Lake Michigan coho and chinook salmon, 19752010. J Great Lakes Res 40(3):748-754

Rivera Monroy VH, Branoff B, Meselhe EA, McCorquodale A, Dortch M, Steyer GD, Visser J, Wang H (2013) Landscape-level estimation of nitrogen loss in coastal Louisiana wetlands: potential sinks under different restoration scenarios. J Coast Res SI(67):75-87

Roy SB, Smith M, Morris L, Orlovsky N, Khalilov A (2014) Impact of the desiccation of the Aral Sea on summertime surface air temperatures. J Arid Environ 110:79-85

Sible E, Cooper A, Malkia K, Bruder K, Watkins SC, Fofanov Y, Putonti C (2015) Survey of viral populations within Lake Michigan nearshore waters at four Chicago area beaches. Data in Brief 5:9-12

Small EE, Sloan LC, Hostetler S, Giorgi F (1999) Simulating the water balance of the Aral Sea with a coupled regional climate-lake model. J Geophys Res 104(D6):6583-6602

Small EE, Sloan LC, Nychka D (2001) Changes in surface air temperature caused by desiccation of the Aral Sea. J Clim 14:284-299

Snedden GA, Cable JE, Swarzenski C, Swenson E (2007) Sediment discharge into a subsiding Louisiana deltaic estuary through a Mississippi River diversion. Estuar Coast Shelf Sci 71(1-2):181193

Ste A, Kordan S (2015) Analysis of profitability of rainwater harvesting, gray water recycling and drain water heat recovery systems. Resour Conserv Recy 105(Part A):84-94

van Steenbergen F, Oliemans W (2002) A review of policies in groundwater management in Pakistan 1950-2000. Water Policy 4(4):323344

Vostokova EA (2004) Ecological disaster linked to landscape composition changes in the Aral Sea basin. In: Glantz MH (ed) Creeping environmental problems and sustainable development in the Aral Sea region. Cambridge Univ. Press, Cambridge, UK, pp 26-46

Wang D (1999) Impact of inter-basin water transfer project on the ecoenvironment abroad and the development tendency. Environ Sci Trend 20(3):28-32, In Chinese 
Wang HC, Jiang YZ, Lu F, Dong YJ (2008) Inspiration of inter-basin water transfer abroad on operation of middle route of south-to-north water transfer project. Adv Sci Technol Water Resour 28(2):79-83 (In Chinese with English abstract)

Wang HQ, Steyer GD, Couvillion BR, Rybczyk JM, Beck HJ, Sleavin WJ, Meselhe EA, Allison MA, Boustany RG, Fischenich CJ, Rivera-Monroy VH (2014) Forecasting landscape effects of Mississippi River diversions on elevation and accretion in Louisiana deltaic wetlands under future environmental uncertainty scenarios. Estuar Coast Shelf Sci 138:57-68

Wang XL (2004) The famous water transfer projects in foreign basins and regions. Water Resour Elec Power 30(1):1-25 (In Chinese)

Wen L, Rogers K, Ling J, Saintilan H (2011) The impacts of river regulation and water diversion on the hydrological drought characteristics in the Lower Murrumbidgee River, Australia. J Hydrol 405(34):382-391

Whish-Wilson P (2002) The Aral Sea environmental health crisis. J Rural Trop Public Health 1:29-34

Wiggs GFS, O'Hara SL, Wegerdt J, Van Der Meer J, Small I, Hubbard RB (2003) The dynamics and characteristics of aeolian dust in dry land Central Asia: possible impacts on human exposure and respiratory health in the Aral Sea basin. Geogr J 169:142-157

$\mathrm{Xu} \mathrm{K,} \mathrm{Zhu} \mathrm{J,} \mathrm{Gu} \mathrm{Y} \mathrm{(2012)} \mathrm{Impact} \mathrm{of} \mathrm{the} \mathrm{eastern} \mathrm{water} \mathrm{diversion} \mathrm{from} \mathrm{the}$ south to the north project on the saltwater intrusion in the Changjiang Estuary in China. Acta Oceanol Sin 31:47-55

Yang LX (2003) Water diversion project abroad. China Waterpower Press, Beijing (In Chinese)

Zhang JP (2012) The study on compensation mechanism innovation in inter-basin water transfer, Ph.D Thesis. Wuhan University, China, In Chinese

Zhao J (2010) Terrestrial water cycle scheme in Heihe River Basin and its responses to human activities, Ph.D Thesis. China University of Geosciences, China, In Chinese

Zhao X, Barlow J, Taylor BL, Pitman RL, Wang K, Wei Z, Stewart BS, Turvey ST, Akamatsu T, Reeves RR, Wang D (2008) Abundance and conservation status of the Yangtze finless porpoise in the Yangtze River. China Biol Conserv 141:3006-3018

Zhao, Z.Y., Zuo, J., Zillante, G., 2015. Transformation of water resource management: a case study of the South-to-North Water Diversion project. J. Clean. Prod. In Press, doi: 10.1016/j.jclepro.2015.08.066. 